\title{
Factors Affecting Consumer's Brand Preference of Small Cars
}

\author{
${ }^{1}$ K. Anandh, ${ }^{2}$ Dr. K. Shyama Sundar \\ ${ }^{1}$ Research Scholar, Bharathiar University, Coimbatore- 641046. \\ ${ }^{2}$ Dean, Department of Management Studies, Mohamed Sathak College of Arts and Science, Chennai- 600119
}

\begin{abstract}
The purpose of this study is to identify the factors affecting consumer's brand preference of small cars in Chennai. The majority of consumers prefer Maruthi Suzki brand of small car. The value, comfortability, efficiency, accessibility, ambition and need are the factors affecting consumer's brand preference of small cars. The regression analysis shows that value, comfortability, efficiency and need are positively influencing the consumer's overall satisfaction about small cars at one per cent level of significance, while accessibility is also positively influencing the consumer's overall satisfaction about small cars at five cent level of significance. Therefore, the small car manufacturers should also focus on value-creating activities as such so that consumers will have a better perception of quality of the brand. By incorporating these factors, it also delivers a functional benefit such as creating a differentiation from industry competitors. There is cut throat competitions in the market on price front and so they have to find out better quality and low cost product. Indians are conscious about the price and fuel efficiency.
\end{abstract}

Key Words: Brand Preference, Explanatory Factor Analysis, Regression, Small Cars,

\section{Introduction}

The automobile market is getting saturated with many models of passenger cars, competing against each other, in sharp contrast to the monopolistic industry behaviour, which was prevalent till late 80 's. The Automobile Industry in India has been in the booming phase for the past 10 years, on the strength of the Indian Government's liberalized economy policy and freedom from the License Raj. The Government of India allowed Foreign Joint Venture in the industry since early 1990. Subsequently, the Indian Government allowed Foreign Direct Investment with an equity cap in the industry, which saw many automobile giants entering the Indian market with their models, readily available, without much waiting time for the delivery.

Sudden interest of major global players has made Indian auto industry very competitive, as India provides twin benefit of ready market and low cost manufacturing base for them. With the explosion of the automobile industry, due to its globalization and liberalization, car manufacturers introduced much innovative and technological advancement in their models. Customers have started thinking to change over to the new models of cars, with related ease than before, to suit their changing life styles.

It requires tremendous amount of marketing efforts to keep and grow their market share in this scenario, by adopting quite innovative features and value added services, which are very attractive to the customers. Companies are adopting new methods to see, if small families using the two wheelers, can be converted into the car buyers. Due to the economic boom, higher income levels and the growing purchasing power of the Indian urban populace, cars have transformed into a necessitated ingredient for Indian middle class families.

Currently, India is one of the largest producers of small cars with the small car segment accounting for about three-fourths of the Indian car market. Small cars are classified according to the price range which varies from 1 to 3 lakhs. It has the capacity to carry 4 passengers- 2 adults, 2 children. These are basically entry level cars which are preferred by service group and middle income group. With this backdrop, the present study is attempted to identify the factors affecting consumer's brand preference of small cars in Chennai.

\section{Methodology}

Among the different cities in Tamil Nadu, the Chennai city has been purposively selected for the present study. The consumers of small cars have been selected by adopting random sampling technique. The data and information have been collected from 500 consumers of small cars through pre-tested and structured questionnaire. In order to understand the socio-economic status of consumers of small cars and brand preference of small cars, the frequency and percentage analysis have been carried out. In order to identify the factors affecting consumer's brand preference of small cars, the exploratory factor analysis has been employed. In order to examine the influence of factors affecting consumer's brand preference on overall satisfaction of consumers about small cars, the multiple linear regression has been applied 


\section{Results And Discussion}

\subsection{Socio-Economic Status Of Consumers}

The socio-economic status of the consumers of small cars was analyzed and the results are presented in Table-1. The results show that about 75.60 per cent of the consumers of small cars are males while the rest of 24.40 per cent of the consumers of small cars are females. The results indicate that about 48.00 per cent of the consumers of small cars belong to the age group of 31- 40 years followed by 21-30 years (28.20 per cent), 41-50 years (19.20 per cent), above 50 years ( 3.60 per cent) and up to 20 years (1.00 per cent).

Table-1. Socio-Economic Status of the Consumers

\begin{tabular}{|c|c|c|}
\hline Particulars & Frequency & Percentage \\
\hline \multicolumn{3}{|l|}{ Gender } \\
\hline Male & 378 & 75.60 \\
\hline Female & 122 & 24.40 \\
\hline \multicolumn{3}{|l|}{ Age(Years) } \\
\hline Up to 20 & 5 & 1.00 \\
\hline $21-30$ & 141 & 28.20 \\
\hline $31-40$ & 240 & 48.00 \\
\hline $41-50$ & 96 & 19.20 \\
\hline Above 50 & 18 & 3.60 \\
\hline \multicolumn{3}{|l|}{ Educational Qualification } \\
\hline No Formal Education & 21 & 4.20 \\
\hline Higher Secondary & 9 & 1.80 \\
\hline Graduation & 163 & 32.60 \\
\hline Post Graduation & 153 & 30.60 \\
\hline Professional & 147 & 29.40 \\
\hline Others & 7 & 1.40 \\
\hline \multicolumn{3}{|l|}{ Occupation } \\
\hline Business & 71 & 14.20 \\
\hline Professionals & 31 & 6.20 \\
\hline Government & 62 & 12.40 \\
\hline Private & 175 & 35.00 \\
\hline MNCs & 143 & 28.60 \\
\hline Retired & 12 & 2.40 \\
\hline Home Maker & 6 & 1.20 \\
\hline \multicolumn{3}{|l|}{ Monthly Household Income ( Rs) } \\
\hline Up to 25000 & 102 & 20.40 \\
\hline $25001-50000$ & 311 & 62.20 \\
\hline $50001-75000$ & 76 & 15.20 \\
\hline $75001-100000$ & 9 & 1.80 \\
\hline Above 100000 & 2 & 0.40 \\
\hline \multicolumn{3}{|l|}{ Marital Status } \\
\hline Married & 400 & 80.00 \\
\hline Unmarried & 100 & 20.00 \\
\hline \multicolumn{3}{|l|}{ Family Type } \\
\hline Nuclear & 322 & 64.40 \\
\hline Joint & 178 & 35.60 \\
\hline
\end{tabular}

It is clear that about 32.60 per cent of the consumers of small cars belong to graduation followed by post graduation (30.60 per cent), professional (29.40 per cent), no formal education (4.20 per cent), higher secondary (1.80 per cent) and other educational qualifications (1.40 per cent). It is observed that about 35.00 per cent of the consumers of small cares are employed in private sector followed by $\operatorname{MNCs}(28.60$ per cent $)$, Government(12.40 per cent), business(14.20 per cent), professionals(6.20 per cent), retired(2.40 per cent) and home maker(1.20 per cent).

It is apparent that about 62.20 per cent of the consumers of small cars belong to monthly household income group of Rs.25000-50000 followed by up to Rs.25000 (20.40 per cent), Rs. $50001-75000$ (15.20 per cent), $75001-100000$ (1.80 per cent) and above Rs. 100000(0.40 per cent). The results show that about 80.00 per cent of the consumers of small care are married, while the rest of 20.00 per cent of the consumers of small cars are unmarried. The results indicate that about 64.40 per cent of the consumers of small cars belong to nuclear family and the rest of 35.60 per cent of the consumers of small cars belong to joint family. 


\subsection{Consumer's Brand Preference Of Small Cars}

The consumer's brand preference of small cars was analysed and the results are presented in Table-2.

Table -2 Consumer's Brand Preference of Small Cars

\begin{tabular}{|l|c|c|}
\hline \multicolumn{1}{|c|}{ Brand } & Frequency & Percentage \\
\hline Maruthi Suzki & 155 & 31.00 \\
\hline Hyundai & 98 & 19.60 \\
\hline Ford & 47 & 9.40 \\
\hline Nissan & 68 & 13.60 \\
\hline Tata & 86 & 17.20 \\
\hline Volkswagen & 9 & 1.80 \\
\hline Honda & 10 & 2.00 \\
\hline Chevrolet & 18 & 3.60 \\
\hline Toyota & 6 & 1.20 \\
\hline Skoda & 3 & 0.60 \\
\hline Total & $\mathbf{5 0 0}$ & $\mathbf{1 0 0 . 0 0}$ \\
\hline
\end{tabular}

The results show that about 31.00 per cent of consumers prefer Maruthi Suzki brand of small car followed by Hyundai (19.60 per cent), Tata(17.20 per cent), Nissan(13.60 per cent), Ford(9.40 per cent), Chevrolet(3.60 per cent), Honda(2.00 per cent), Volkswagen(1.80 per cent), Toyota(1.20 per cent) and Skoda(0.60 per cent).

\subsection{Factors Affecting Consumer's Brand Preference Of Small Cars}

In order to identify the factors affecting consumer's brand preference of small cars, the exploratory factor analysis has been employed. The principal component method of factor analysis was carried out with Eigen values greater than one through varimax rotation and the results obtained through rotated component matrix are presented in Table-3. The results of Kaiser-Meyer-Olkin (KMO test) measure of sampling adequacy $(\mathrm{KMO}=0.917)$ and Bartlett's test of Sphericity ( chi-square value $=0.0003$; significance $=0.000$ ) indicates that the factor analysis method is appropriate.

There are six independent groups which are extracted accounting for a total of 81.01 per cent of variations on 40 attributes. The each of the six factors contributes to 18.71 per cent, 18.52 per cent, 12.76 per cent, 11.36 per cent, 10.72 per cent and 8.94 per cent respectively.

Table -3. Factors Affecting Consumer's Brand Preference of Small Cars - Exploratory Factor Analysis

\begin{tabular}{|c|c|c|c|c|c|c|}
\hline Factor & Item & $\begin{array}{c}\text { Rotated } \\
\text { Factor } \\
\text { Loadings }\end{array}$ & $\begin{array}{l}\text { Eigen } \\
\text { Value }\end{array}$ & $\begin{array}{c}\% \text { of } \\
\text { Variation }\end{array}$ & Cronbach's Alpha & Factor Name \\
\hline I & $\begin{array}{l}\text { Superior quality } \\
\text { Value for money } \\
\text { Market good will } \\
\text { Security } \\
\text { Entertainment } \\
\text { Safety } \\
\text { Prestige value } \\
\text { Dealer offer } \\
\text { Esteem } \\
\text { Less emission }\end{array}$ & $\begin{array}{l}0.62 \\
0.62 \\
0.69 \\
0.76 \\
0.62 \\
0.78 \\
0.74 \\
0.80 \\
0.83 \\
0.74\end{array}$ & 2.42 & 18.71 & 0.94 & Value \\
\hline II & $\begin{array}{l}\text { Comfortable } \\
\text { Affordable price } \\
\text { Position in the society } \\
\text { Compactness } \\
\text { Good design } \\
\text { Spacious } \\
\text { Range of colours } \\
\text { Fashion conscious } \\
\text { Low fuel consumption } \\
\text { Time saving }\end{array}$ & $\begin{array}{l}0.68 \\
0.78 \\
\\
0.78 \\
0.78 \\
0.57 \\
0.72 \\
0.68 \\
0.69 \\
\\
0.64 \\
0.56\end{array}$ & 2.26 & 18.52 & 0.93 & 更 \\
\hline III & $\begin{array}{l}\text { Good mileage } \\
\text { Less maintenance and } \\
\text { repairs } \\
\text { Low maintenance cost } \\
\text { After sales service } \\
\text { Availability of spare } \\
\text { parts } \\
\text { Availability of service }\end{array}$ & $\begin{array}{l}0.71 \\
0.61 \\
\\
0.55 \\
0.58 \\
\\
0.75\end{array}$ & & & & \\
\hline
\end{tabular}




\begin{tabular}{|c|c|c|c|c|c|c|}
\hline & centers & 0.71 & 1.86 & 12.76 & 0.92 & Efficiency \\
\hline IV & $\begin{array}{l}\text { Accessible } \\
\text { Brand image } \\
\text { Availability of test } \\
\text { driving } \\
\text { Arrangements } \\
\text { finance } \\
\text { Easy installments } \\
\text { Simplified procedure } \\
\text { Immediate delivery }\end{array}$ & $\begin{array}{l}0.55 \\
0.59 \\
0.61 \\
0.65 \\
0.55 \\
0.60 \\
0.59\end{array}$ & 1.71 & 11.36 & 0.93 & Accessibility \\
\hline $\mathbf{V}$ & $\begin{array}{l}\text { Need for upgrade from } \\
\text { two- wheeler to four- } \\
\text { wheeler } \\
\text { Family use } \\
\text { Attractiveness } \\
\text { Ambition of females } \\
\text { Ambition of males }\end{array}$ & $\begin{array}{l}0.60 \\
0.71 \\
0.79 \\
\\
0.83 \\
0.88\end{array}$ & 1.23 & 10.72 & 0.92 & Ambition \\
\hline VI & $\begin{array}{l}\text { Personal needs / wants } \\
\text { Inconvenience in public } \\
\text { transport }\end{array}$ & $\begin{array}{l}0.78 \\
0.86\end{array}$ & 1.13 & 8.94 & 0.90 & Need \\
\hline & $\begin{array}{lll}\begin{array}{l}\text { Cumulative } \\
\text { Variation }\end{array} & & \text { of } \\
\end{array}$ & & & 81.01 & & \\
\hline & Cronbach's Alpha & & & 0.93 & & \\
\hline
\end{tabular}

Extraction Method: Principal Component Analysis.

Rotation Method: Varimax with Kaiser Normalization.

Rotation converged in 8 iterations.

The overall Cronbach's alpha of the scale is 0.93 indicating that each measure demonstrates acceptable internal consistency. The cronbach's alpha of the scale is varying from 0.90 for need to 0.94 for value shows that each items in different factors also demonstrates acceptable internal consistency. It is inferred that value, comfortability, efficiency, accessibility, ambition and need are the factors affecting consumer's brand preference of small cars.

\subsection{Influence Of Factors Affecting Consumer's Brand Preference On Overall Satisfaction Of Consumers} About Small Cars

In order to examine the influence of factors affecting consumer's brand preference on overall satisfaction of consumers about small cars, the multiple linear regression has been applied and the results are presented in Table-4. The factors derived through factor analysis are considered as independent variables and the consumer's overall satisfaction about small cars is considered as dependent variable.

The results indicate that the coefficient of multiple determination $\left(R^{2}\right)$ is 0.69 and adjusted $R^{2}$ is 0.67 indicating the regression model is good fit. It is inferred that about 67.00 per cent of the variation in dependent variable (Overall Satisfaction) is explained by the independent variables (Factors Affecting Brand Preference of Small Cars). The F-value of 5.962 is statistically significant at one per cent level indicating that the model is good fit.

Table-4. Influence of Factors Affecting Consumer's Brand Preference on Overall Satisfaction of Consumers about Small Cars -Multiple Regression

\begin{tabular}{|c|c|c|c|}
\hline Factors Affecting Loyalty Programmes & Regression Coefficients & t-value & Sig \\
\hline Intercept & $1.156^{* *}$ & 3.968 & .010 \\
\hline Value $\left(\mathrm{X}_{1}\right)$ & $.642^{* *}$ & 3.857 & .011 \\
\hline Comfortability $\left(\mathrm{X}_{2}\right)$ & $.594^{* *}$ & 3.562 & .010 \\
\hline Efficiency $\left(\mathrm{X}_{3}\right)$ & $.528^{* *}$ & 3.756 & .011 \\
\hline Accessibility $\left(\mathrm{X}_{4}\right)$ & $.446^{*}$ & 2.396 & .032 \\
\hline $\operatorname{Ambition}\left(\mathrm{X}_{5}\right)$ & .308 & 1.104 & .524 \\
\hline $\operatorname{Need}\left(X_{6}\right)$ & $.514^{* * 6}$ & 3.695 & .010 \\
\hline $\mathrm{R}^{2}$ & 0.69 & & \\
\hline Adjusted $\mathrm{R}^{2}$ & 0.67 & & \\
\hline $\mathrm{F}$ & 5.962 & & 0.00 \\
\hline $\mathrm{N}$ & 500 & & \\
\hline
\end{tabular}


Note: ${ }^{* *}$ Significance at one per cent level

* Significance at five per cent level

The results show that value, comfortability, efficiency and need are positively influencing the consumer's overall satisfaction about small cars at one per cent level of significance, while accessibility is also positively influencing the consumer's overall satisfaction about small cars at five cent level of significance.

\section{Conclusion}

The majority of the consumers of small cars are males and the most of the consumers of small cars belong to the age group of 31- 40 years. The majority of the consumers of small cars are graduates and the most of the consumers of small cars are employed in private sector. The majority of the consumers of small cars belong to monthly household income group of Rs.25000-50000 and the most of the consumers of small cars are married. The majority of the consumers of small cars belong to nuclear family.

The majority of consumers prefer Maruthi Suzki brand of small car.The value, comfortability, efficiency, accessibility, ambition and need are the factors affecting consumer's brand preference of small cars. The regression analysis shows that value, comfortability, efficiency and need are positively influencing the consumer's overall satisfaction about small cars at one per cent level of significance, while accessibility is also positively influencing the consumer's overall satisfaction about small cars at five cent level of significance. Therefore, the small car manufacturers should also focus on value-creating activities as such so that consumers will have a better perception of quality of the brand. By incorporating these factors, it also delivers a functional benefit such as creating a differentiation from industry competitors. There is cut throat competitions in the market on price front and so they have to find out better quality and low cost product. Indians are conscious about the price and fuel efficiency. Whoever is selling low-priced, fuel-efficient small cars will succeed and they are likely to see large volumes of sales. Hence, the small car makers should concentrate on all these factors in their production and marketing plans

\section{References}

[1]. Andreas Herrmann, Lan Xia, Kent B. Monroe and Frank Huber (2007), "The Influence of Price Fairness on Customer Satisfaction: An Empirical Test in the Context of Automobile Purchases", Journal of Product \& Brand Management, 16(1): pp. 49-58.

[2]. Archer, N. P., and Wesolowsky, G. O., (1996), "Consumer Response to Service and Product Quality: A Study of Motor Vehicle Owners", Journal of Operations Management, 14(2): pp. 103-118.

[3]. Cayla, J., and Eckhardt, G.M., (2007), "Asian Brands without Borders: Regional Opportunities and Challenges", International Marketing Review, 24(4): pp. 444-456.

[4]. Chidambaram and Alfread(2007), “A Study on Brand Preference of Passenger Car with Reference to Coimbatore City", Indian Journal of Marketing, 34(9): pp.24-30.

[5]. Kwak, L.E., and Sojka, J.Z., (2010), "If They Could See Me Now: Immigrants' Use of Prestige Brands to Convey Status", Journal of Consumer Marketing, 27(4): pp. 371-380.

[6]. Mandeep Kaur and Sandhu, H.S.,(2006), "A Study on Factors Influencing Buying Behaviour of Passenger Car Market", Paradigm, 8(2): pp.54-69.

[7]. Nataraj. S., and Nagaraja, N.,(2012), "Customer Satisfaction in Automobile Industry - An Indian Online Buyers' Perspective of Car Manufacturers' Websites”, International Journal of Multidisciplinary Research, 2(6):pp.92-107.

[8]. Natarajan, P., and Thiripurasundari, U.,(2010), "A Study on Brand Preference of 'B' Segment cars" (with ref. to Maruti Cars)", International Journal of Business Intelligence and Management, 2(1-2): pp. 165-174.

[9]. O’Cass, A., and Frost, H., (2004), "Status Brands: Examining the Effects of Non-Product-Related Brand Associations on Status and Conspicuous Consumption", Journal of Product \& Brand Management, 11(2): pp. 67-88.

[10]. Ramesh Sardar(2012), “ Brand Preference of Passenger Cars in Aurangabad District”, International Journal of Multidisciplinary Research, 2(3): pp.431-442. 